\title{
原著論文
}

\section{健常有歯顎者の歯根膜触・圧覚閾值と矯正治療後に生じた 咬合違和感の閾值の経時的変化}

\author{
向井憲夫, 谷岡款相, 久保大樹, 龍田光弘, 田中順子, 田中昌博 \\ 大阪歯科大学有歯補綴咬合学講座 \\ 〔受付：平成23年 3 月29日〕
}

\author{
Periodontal mechanosensitive thresholds of adult subjects \\ with natural dentition and chronological change of the threshold \\ with uncomfortable occlusion after orthodontic treatment
}

\author{
Norio Mukai, Tadasuke Tanioka, Hiroki Kubo, \\ Mitsuhiro Tatsuta, Junko Tanaka, Masahiro Tanaka \\ Dept. of Fixed Prosthodontics and Occlusion, Osaka Dental University
}

[Received: March 29, 2011]

Key words: periodontal mechanosensitive threshold, uncomfortable occlusion, intercuspal position, occlusal contact

\begin{abstract}
Purpose: The number of patients complaining of uncomfortable occlusion has recently increased. However, methods for differentiating dysesthesia from disorder of aesthesia causing uncomfortable occlusion have not been established. The purposes of this study were to set the normal range of periodontal mechanosensitive threshold in adult dentulous persons and to utilize clinically.

Methods: 32 adult dentulous subjects (20 males and 12 females, mean age: $26.1 \pm 3.7$ years) with normal dentition evaluated by add picture regulated bite force were selected. The subject teeth were 28 teeth between the bilateral second molar on maxillary and mandibular. Measurement was performed with their eyes closed, sitting on a chair. In measuring periodontal mechanosensitive threshold, von Frey's hair came into contact with the subject teeth from the labio-buccal surface side, and stimulation was applied in the lingual direction. Measurement was performed by a dentist with sufficient knowledge and training, and thresholds were determined applying the up-down method of the method of limits of psycho-physical measurement methods. The interquartile range of periodontal mechanosensitive threshold of the normal subjects was calculated.

Periodontal mechanosensitive threshold of the man complained uncomfortable occlusion after orthodontic treatment were measured from one month after the removal of the device every the $14^{\text {th }}$.

Results: There were no abnormal occlusal contact both normal subjects and clinical case. It was shown that periodontal mechanosensitive threshold gradually increased from the anterior tooth to molar area. The interquartile range of periodontal mechanosensitive threshold was $0.5-1.7 \mathrm{~g}$ in the maxillary anterior tooth area, $1.5-3.0 \mathrm{~g}$ in the
\end{abstract}

連絡先： $=540-0008$ 大阪府大阪市中央区大手前 1 丁目 5 番 17 号

TEL: 06-6910-1518 FAX: 06-6910-1046 
canine teeth, 1.5-4.0g in the premolar area, and 3.7-8.8g in the molar area. The interquartile range of periodontal mechanosensitive threshold was $0.3-1.0 \mathrm{~g}$ in the mandibular anterior tooth area, $0.7-3.0 \mathrm{~g}$ in the canine teeth, $0.8-5.0 \mathrm{~g}$ in the premolar area, and 3.0-11.6g in the molar area.

Periodontal mechanosensitive threshold when one month passed was $190.0 \mathrm{~g}$ or less in molar teeth and was $7.0 \mathrm{~g}$ or less in anterior teeth. Afterwards, the value of periodontal mechanosensitive threshold was decreased. The value of periodontal mechanosensitive threshold when three months passed after removal device was decreased until the interquartile range, and uncomfortable occlusion was disappeared. The change was not shown in periodontal mechanosensitive threshold and uncomfortable occlusion when seven months passed after removal device.

Conclusion: These results revealed that periodontal mechanosensitive threshold become objective index of sensitive of teeth.

抄録 目的：近年，咬合違和感を訴える患者が増加している。しかし，感覚の異常を診断する方法は確立 されていない.そこで，歯の感覚の測定に用いられてきたvon Freyの毛を用いて，健常有歯顎者の歯根 膜触・圧覚閾值の臨床的参考值を求め, 臨床応用することを目的とした.

方法：健常被験者として，噛みしめ強度を規定した add 画像から咬合接触像に異常を認めず，咬合違和 感を認めない成人有歯顎者 32 名（男性 20 名，女性 12 名，平均年齢 $26.1 \pm 3.7$ 歳）を選択した。 上下顎左 右側中切歯から第二大臼歯までの計 28 歯を対象とした。座位，閉眼状態で測定した。歯根膜触・圧覚閾 值の測定には von Freyの毛（touch test, North Coast Medical 社）を用いて，唇・㚘側面から舌側方向へ 刺激した。閾值の決定には精神物理学的測定法の極限法の上下法を用い，本法を熟知・訓練した歯科医師 1 名が測定した．被検歯の歯根膜触・圧覚閾值の四分位範囲を求めた.

その範囲の臨床的意義を確かめるために，矯正治療後に咬合違和感を訴えた成人男性（25歳）の歯根 膜触・圧覚閾值を，矯正装置除去 1 カ月から，14日間隔で経時的に観察した.

結果：健常被験者および臨床例ともに咬合接触像に異常を認めなかった.

歯根膜触・圧覚閾值は前歯部から臼歯部にかけて増加していく傾向を示した。四分位範囲は，上顎では 切歯部 $0.5 \sim 1.7 \mathrm{~g}$, 犬歯 $1.5 \sim 3.0 \mathrm{~g}$, 小臼歯部 $1.5 \sim 4.0 \mathrm{~g}$, 大臼歯部 $3.7 \sim 8.8 \mathrm{~g}$ であった. 下顎では切歯部 0.3 $\sim 1.0 \mathrm{~g}$, 犬歯部 $0.7 \sim 3.0 \mathrm{~g}$ ，小臼歯部 $0.8 \sim 5.0 \mathrm{~g}$ ，大臼歯部で $3.0 \sim 11.6 \mathrm{~g}$ であった.

一方，矯正装置除去 1 力月経過時の歯根膜触・圧覚閾值は，大的歯部で最大 $190.0 \mathrm{~g} ，$ 前歯部で最大 $7.0 \mathrm{~g}$ であった。その後, 值は減少し, 装置除去 3 カ月経過時に四分位範囲内へ収束し, 咬合違和感も消 失した。装置除去 7 カににおいても歯根膜触・圧覚閾值ならびに咬合違和感に変化は認められなかった. 結論：以上のことから，歯根膜触・圧覚閾值が歯の感覚の客観的指標となることがわかった.

キーワード：歯根膜触・圧覚閾值，咬合違和感，咬頭嵌合位，咬合接触

\section{I. 緒言}

咬合違和感は, 患者が感じる咬合時の違和感の総称で ある。窪木は咬合違和感を, 咬合を軸として分類し，そ れぞれにおいて広義の咬合違和感の存在を提唱してい る ${ }^{1)}$. またCrark らは咬合違和感に近い用語として咬合 異常感症（occlusal dysesthesia）を提唱し，「歯髄疾患， 歯周疾患, 咀嚼筋ならびに顎関節疾患のいずれもが認め られず，臨床的に咬合異常が認められないにもかかわら ず 6 カ月以上持続する咬頭嵌合位の不快感」 ${ }^{2)}$ と定義し
ており，それらをふまえて，玉置らは咬合違和感を「明 らかな咬合の不調和が認められる場合，また明らかな咬 合の不調和が認められない場合も含めて歯・歯周組織・ 咀嚼筋 · 顥関節 · 未梢神経 (神経接合部)，末梢 - 中枢 の問題によって惹起され，上下顎の接触，歯や歯列自 体に関する何らかの感覚や知覚の不具合 $\rfloor^{3)}$ としてい. その原因は器質的要素, 知覚的要素もしくは精神的要素 によるものなど様々である ${ }^{1-4)}$ 。しかしながらこれらを 鑑別する評価基準はいまだ確立されていない.

器質的要素として咬合が挙げられる。これまでわれわ 


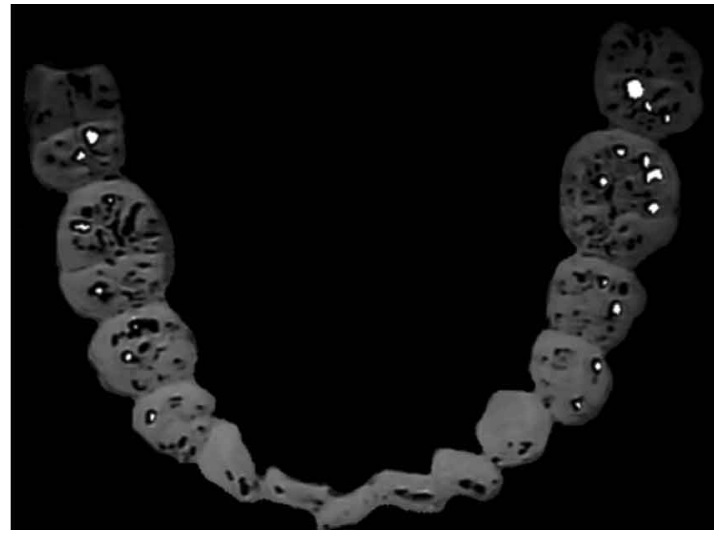

図 $1 \mathrm{a}$ 健常者の一例：10\%MVC 時の $10 \mu \mathrm{m}$ 以下の領 域 (白色部) の add 画像

Fig. 1a The normal case: the add picture of occlusal contact area (white area) less than $10 \mu \mathrm{m}$ during 10\% MVC.

れは咬合接触像を add 画像法 ${ }^{5-7)}$ を用いることにより可 視化し, 真の咬合接触に近い上下顎歯間距離 $10 \mu \mathrm{m}$ 以 下の領域の咬合接触像を観察してきた。 その結果，健常 者の咬頭嵌合位での正常咬合の基準 ${ }^{8)}$ を報告してきた。

知覚的要素として歯根膜触・圧覚閾値異常が挙げら れる。歯根膜触・圧覚閾值の測定器具はvon Frey の 毛 $^{9,10)}$ ，ひずみゲージ ${ }^{11,12)}$ またはエステジオメーター ${ }^{10)}$ が挙げられる。これらを用いてこれまで, 局部床義歯 の鉤歯 ${ }^{13)}$ ，移植歯 ${ }^{14)}$ およびインプラントの触・圧覚閾 值 ${ }^{13)}$ について報告されている。歯根膜触・圧覚閾值を 測定することにより，ヒトの知覚能が客観的に評価可能 といわれる。しかし臨床判断を下す際に必要な正常範囲 は設定されていない.

咬合違和感の原因が咬合接触であるかどうかをまず検 査し，次いで歯根膜触・圧覚閾值の検査を行うことで， 知覚的な要因, つまり歯根膜の触・圧覚が原因である咬 合違和感を診断可能となり，咬合違和感の原因を診断す る一助となると思われる。

われわれはvon Freyの毛を用いて，成人有歯顎者の 歯根膜触・圧覚閾值の臨床的に参考となる範囲を設定し, 咬合接触と歯根膜触・圧覚が関係する咬合違和感の診断 への臨床応用を目的として，本研究を行った。

\section{II. 研究方法}

\section{1．被験者および対象歯}

被験者に上下顎左右側中切歯から第二大的歯までに久

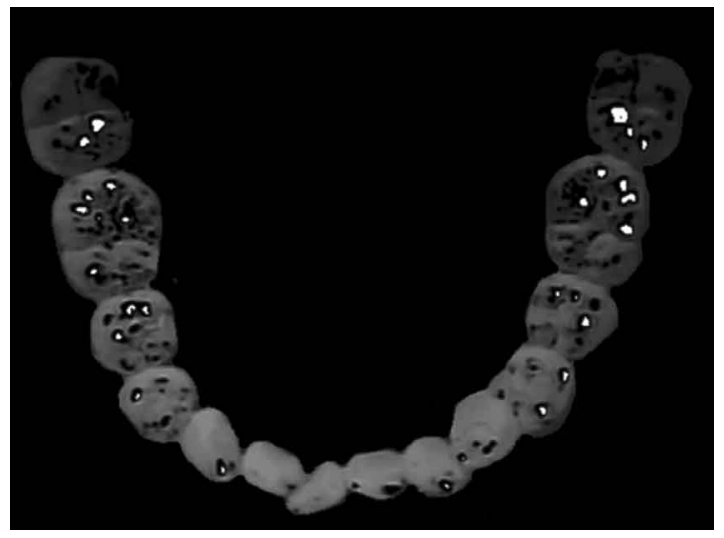

困 $1 \mathrm{~b}$ 健常者の一例：30\%MVC 時の $10 \mu \mathrm{m}$ 以下の領 域（白色部）の add 画像

Fig. 1b The normal case: the add picture of occlusal contact area (white area) less than $10 \mu \mathrm{m}$ during 30\% MVC.

損歯を認めず，矯正治療の既往がなく，咬みしめ強度 を規定した add 画像（図 $1 \mathrm{a} ， 1 \mathrm{~b}$ ）功咬合接触像に 異常を認めず，咬合違和感を認めず，研究の主旨の説明 にインフォームドコンセントが得られた，個性正常咬合 を有する 20 代の健常有歯顎者 32 名（男性 20 名，女性 12 名，平均年齢 $26.1 \pm 3.7$ 歳）を選択した。

対象歯を上下顎左右側中切歯から第二大臼歯までの計 28歯とした.

なお，本研究は大阪歯科大学医の倫理委員会（大歯医 倫 100506）によって承認を得た.

\section{2．測定方法}

1) 咬合接触像の観察

咬合接触関係の観察 ${ }^{15}$ )には，咬合接触検査材（バイ トチェッカー，ジーシー社）を用いた。片側の咬筋中 央部に表面電極（EMG Sensor DE-2.1，DELSYS 社）を 筋繊維の走行に沿わせて貼付し筋電位を双極性に導出 した。筋電位を EMG Evaluation System（Bagnoli-2, DELSYS 社)，データ収集システム（UAS-108B，ユ ニークメディカル社）を用いて時定数を 0.03 秒，サン プリング周波数を $1 \mathrm{KHz}$ ，増幅 1000 倍，広域遮断周波 数を $1 \mathrm{KHz}$ として $\mathrm{A} / \mathrm{D}$ 変換を行い, 生体情報解析ソ フト (Unique Acquisition, ユニークメディカル社) を インストールした PCの画面に RMS 整流波形を表示し てビジュアルフィードバックした（図 2 )。咬頭嵌合 位での咬みしめ強度を，最大随意咬みしめ（Maximum Voluntary clenching：以下 MVC) 時の RMS 整流值を 


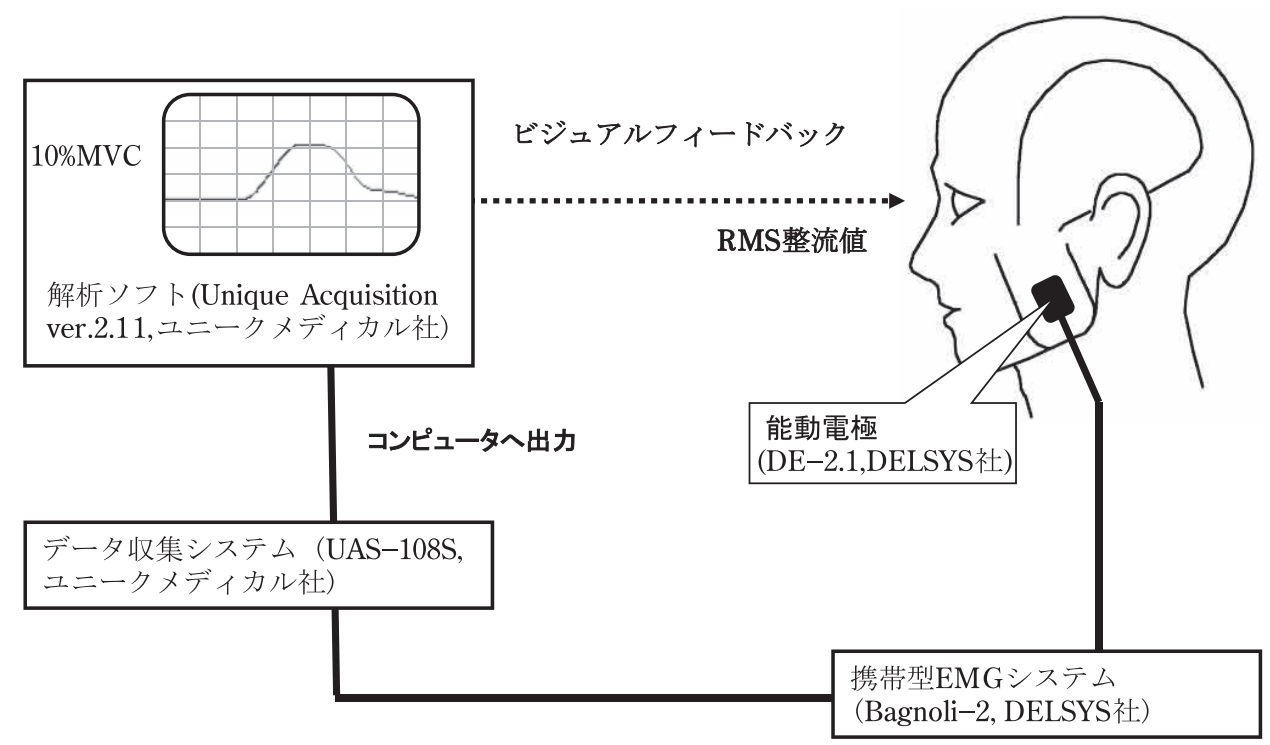

図 2 咬筋筋電図整流波形のビジュアルフィードバックによる咬みしめ強度の規定

Fig. 2 Regulation of occlusal force by visual-feedback of rectified EMG of masseter Muscle.

100\% MVC とした時の 10\% MVC と 30\% MVC とした.

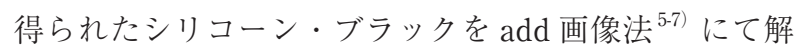
析した。咬合接触と判定するシリコーン・ブラックの厚 みは上下顎歯間距離 $10 \mu \mathrm{m}$ に設定した。

2 ) 歯根膜触・圧覚閾値の測定

各歯における歯根膜触・圧覚閾值は, von Frey の毛 (TOUCH TEST ${ }^{\circledR}$, North Coast Medical 社) を用いて 測定した。被験者をへッドレスト付きの歯科用診療椅子 に座らせ, 閉眼状態を指示し, アングルワイダーを装着 させた。刺激部位上歯面にサージカルテープ（マイクロ ポア, $3 \mathrm{M}$ 社）を貼付し, 毛の先を接触させ, 歯根膜触· 圧覚閾值を測定した（図 3 )。刺激部位は歯冠側 $1 / 3$ か つ近遠心的中央部とし, 唇 - 㚘側面から舌側方向へ刺激 した。刺激速度は可及的にゆっくりとした。

歯根膜触・圧覚閾值の決定には, 精神物理学的測定 法の極限法の一つである上下法を用いた（図 4 ). 刺激 強度を小から大へと, 一方向にのみ刺激を与える上昇 系列において, 被験者が初めて連続して刺激を知覚した 時に知覚できた最小の荷重值と, 知覚できなかった最大 荷重值との中央值を, 上昇系列の変曲点とした。また刺 激強度を大から小へと一方向にの久刺激を加える下降系 列に扔いて, 初めて連続して刺激が知覚できなかった時 に, 知覚できた最小の荷重值と知覚できなかった最大荷 重值との中央值を, 下降系列の変曲点とした。 上昇系列 と下降系列を 2 回測定し, 反応が安定しない場合は安定

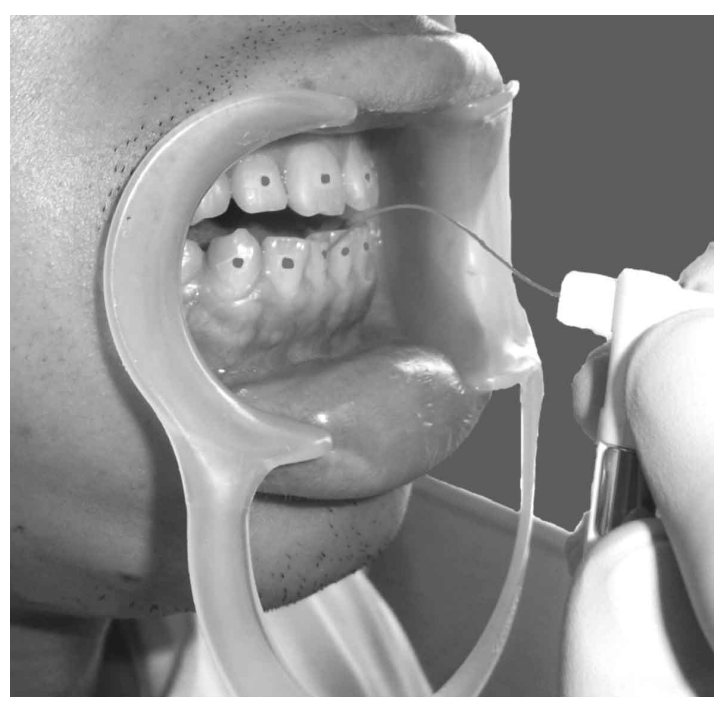

図 3 von Frey の毛を用いた歯根膜蝕・圧覚閾值の測 定風景

Fig. 3 Measurement scenery of periodontal mechanosensitive threshold using von Frey's hair.

するまで測定を繰り返し，安定した 2 サイクルを測定值 とした。 上昇系列で得られた変曲点と下降系列で得られ た変曲点との中央值を，歯根膜触・圧覚閾值とした。得 られた各歯の歯根膜触・圧覚閾值から四分位範囲を算出 した。 


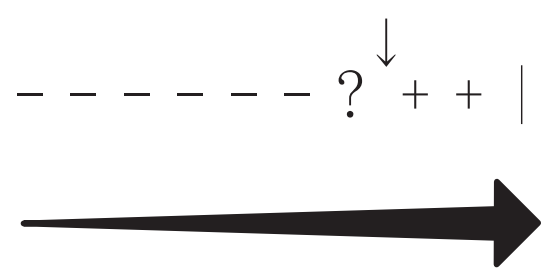

上昇系列

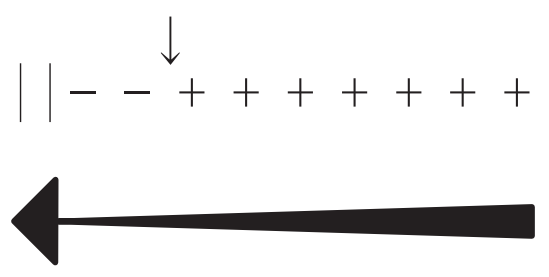

下降系列

図 4 精神物理学的測定法極限法：上下法

+ ：感じた - : 感じない？：感じたかどうか疑わしい

$\|$ ：測定の打ち切り $\downarrow$ : 変曲点

: 刺激強度

Fig. 4 Method of limits of psychophysical method: upper and lower method. + : reaction to feel stimulate - : reaction not to feel stimulate

? : reaction to feel yes or no $\|$ : the end of the measurement $\downarrow$ : inflection point : strength of stimulate

\section{3. 臨床例}

矯正治療後に，歯が浮いた様に感じ噛むことができ ない，という咬合違和感を訴えた成人男性（25歳）を 選択した。歯槽性の Angle III 級症例であり, マルチブ ラケット装置（0.022 slot bracket Roth type）を用い矯 正治療を行った。 また, 上下顎レベリング後に交叉ゴム （TOMY 社）を用いて，臼歯部交叉咬合を矯正した。 2 年 7 カ月の動的治療期間を経て, 静的治療へ移行した.

\section{1 ) 咬合接触像}

前述と同様に，咬合採得を行い，シリコーン・ブラッ クから add 画像を作成し, 初診時（矯正装置除去後 1 力 月後) の咬合接触像を解析した.

2 ）歯根膜触・圧覚閾值の経時的変化

前述と同様に下顎左右側中切歯から第二大的歯までの 計 14 歯の歯根膜触・圧覚閾值を測定した。矯正装置除 去 1 カ月後から 2 週間間隔で 7 カ月間, 歯根膜触 ·圧覚 䦭值とともに咬合違和感の自覚の変化についても経過観 察した。

\section{III. 結 果}

\section{1. 健常有歯顎者の咬合接触像について}

咬合違和感を認めない健常有歯顎者の咬合接触像は, 両側臼歯に接触を認め，10\% MVC および30\% MVCの 咬みしめ強度においても接触の位置は変化しなかった。

\section{2. 健常有歯顎者の歯根膜触・圧覚閾值の四分位範囲に ついて}

健常有歯顎者の上顎第二大臼歯から中切歯の閾值（図
5 ）および下顎第二大的歯から中切歯の閾值（図 6) を 示す。歯の触・圧覚閾值は前歯部から甶歯部にかけて 徐々に大きい值を示す傾向を示した。

四分位範囲は，上顎では．切歯部 $0.5 \sim 1.7 \mathrm{~g}$, 犬歯 1.5 $\sim 3.0 \mathrm{~g}$, 小臼歯 $1.5 \sim 4.0 \mathrm{~g}$, 大臼歯 $3.7 \sim 8.8 \mathrm{~g}$ であっ た. 下顎では切歯部 $0.3 \sim 1.0 \mathrm{~g}$, 犬歯部 $0.7 \sim 3.0 \mathrm{~g}$, 小 臼歯部 $0.8 \sim 5.0 \mathrm{~g}$, 大臼歯部で $3.0 \sim 11.6 \mathrm{~g}$ であった。

\section{3. 臨床例の咬合接触像について}

矯正装置除去 1 力月後の add 画像法による咬合接触 像を示す (図 $7 \mathrm{a}, 7 \mathrm{~b}$ )。10\% MVC 時に下顎両側臼歯 部に咬合接触を認め，また $30 \% \mathrm{MVC}$ 時にも下顎両側臼 歯部に $10 \mu \mathrm{m}$ 以下の領域で咬合接触を認めた。しかも $10 \% \mathrm{MVC}$ 時と $30 \% \mathrm{MVC}$ 時に咬合接触の位置は変化し ていなかった。 その後 7 カ月経過後まで咬合接触像に経 時的な変化は認められなかった。

\section{4. 臨床例の歯根膜触・圧覚閾値について}

矯正装置除去 1 力月経過時の歯根膜触・圧覚閾值は 切歯部最大 $7.0 \mathrm{~g}$, 小臼歯部最大 $44.5 \mathrm{~g}$, 大兒歯部最大 $190.0 \mathrm{~g}$ であり, 大白歯部では四分位範囲の上限の約 36 倍であった．右側第一大臼歯および第二大臼歯の歯根膜 触・圧覚閾值は左側同名歯より大きかった。 その後歯根 膜触・圧覚閾值は経時的に減少した。 4 力月経過時には 歯根膜触・圧覚閾值は急激に減少し, 両側ともに切歯, 犬歯，小臼歯および大臼歯の歯根膜触・圧覚閾值は四分 位範囲内に収束した（図 8). 装置除去後 $6 \sim 7$ 力月経 過時にもすべての歯の触・圧覚閾值に変動を認めなかっ た. (図 9 ). 


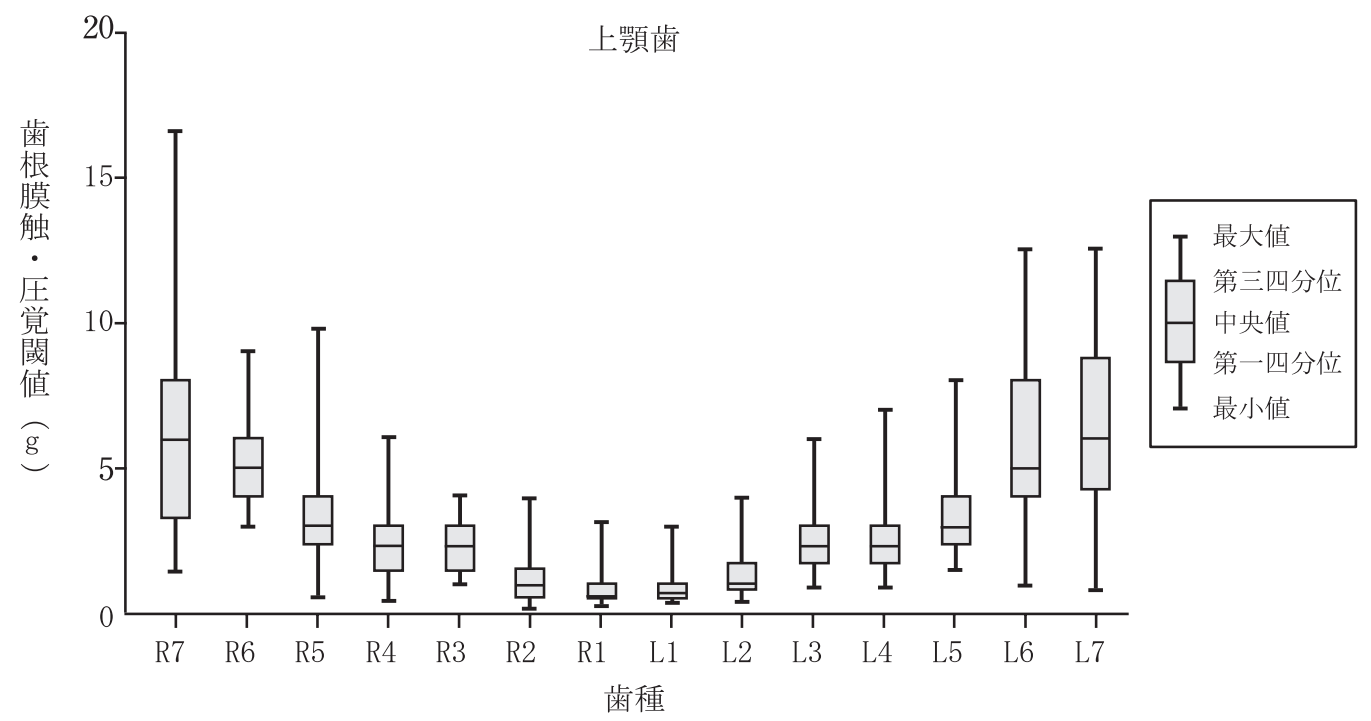

困 5 健常有歯顎者における上顎の歯根膜触・圧覚閾值

Fig. 5 Periodontal mechanosensitive threshold of maxillary teeth of adult with natural dentition.

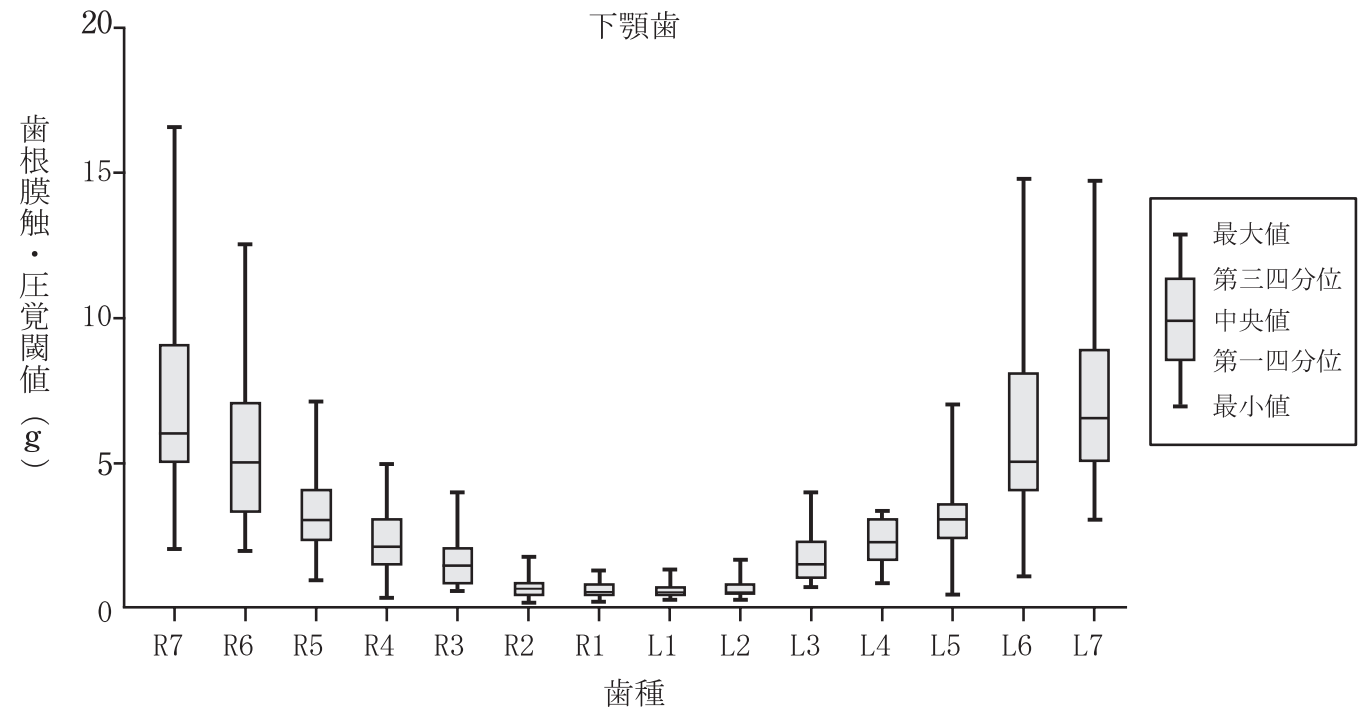

困 6 健常有歯顎者における下顎の歯根膜触・圧覚閾值

Fig. 6 Periodontal mechanosensitive threshold of mandibular teeth of adult with natural dentition.

5. 咬合違和感の自覚について

歯根膜触・圧覚閾值がほぼ四分位範囲に収束した矯正 装置除去 3.5 力月経過時に, 咬合違和感は消失した。そ の後，咬合違和感は出現しなかった。

\section{N. 考 察}

1. 測定方法について

被験者に，歯の欠損がなく，歯冠修復処置が少なく， 重度の歯周疾患に罹患している可能性が低い，20代成 


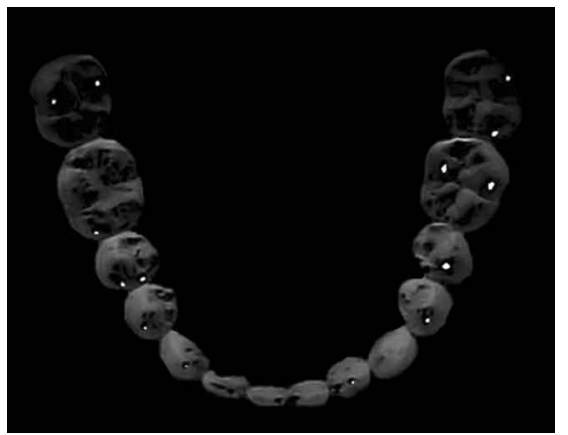

図 $7 \mathrm{a}$ 臨床例（矯正装置除去後 1 力月後）：10\%MVC 時の $10 \mu \mathrm{m}$ 以下の領域 (白色部) の add 画像

Fig. 7a Clinical case (one month after orthodontic treatment): add picture of occlusal contact area (white area) less than $10 \mu \mathrm{m}$ during 10\% MVC.

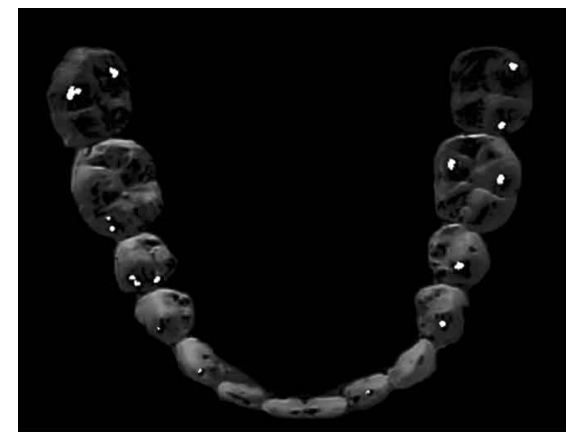

図 $7 \mathrm{~b}$ 臨床例（矯正装置除去後 1 力月後）：30\%MVC 時の $10 \mu \mathrm{m}$ 以下の領域（白色部）の add 画像

Fig. 7b Clinical case (one month after orthodontic treatment): add picture of occlusal contact area (white area) less than $10 \mu \mathrm{m}$ during $30 \%$ MVC.

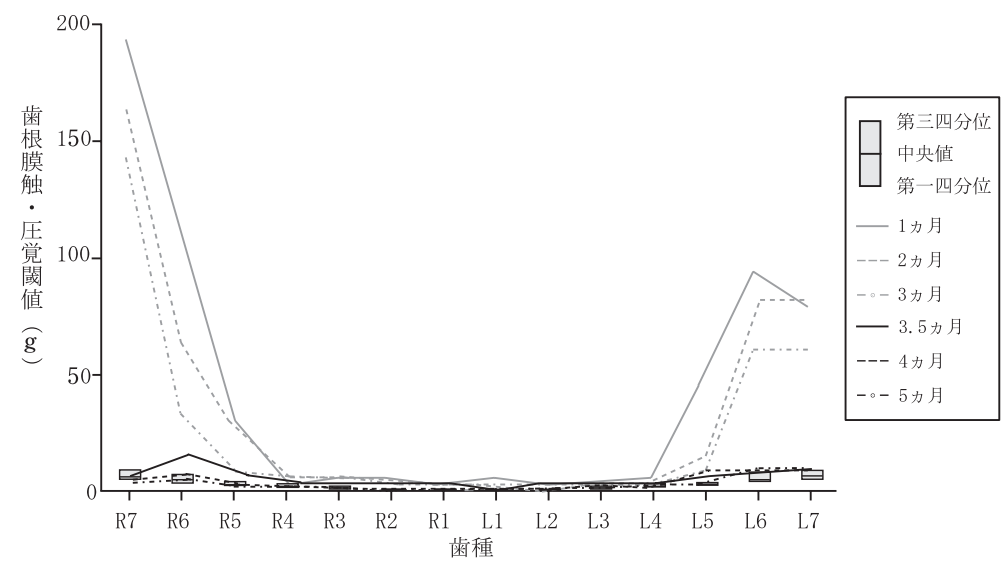

図 8 矯正装置除去後 $1 \sim 5$ 力月に扮ける歯根膜触・圧覚閾值の経時的变化

Fig. 8 Time series of periodontal mechanosensitive threshold during from one to five months after orthodontic treatment.

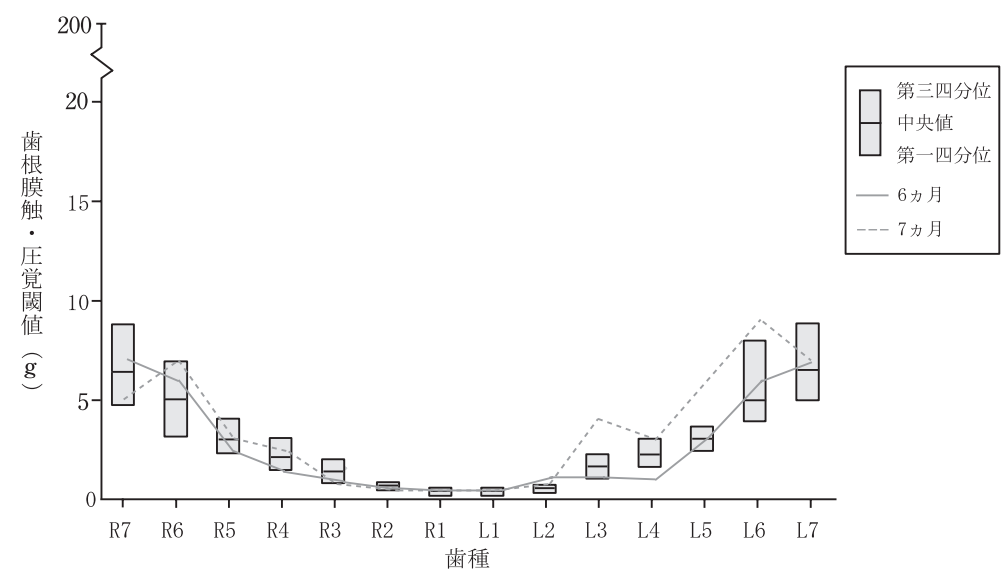

図 9 矯正治療除去後 $6 \sim 7$ カ月に打ける歯根膜触・圧覚閾值の経時的変化

Fig. 9 Time series of periodontal mechanosensitive threshold during from six to seven months after orthodontic treatment. 
人有歯顎者を選択した。歯根膜触・圧覚の測定に際し て，刺激付与を視認することで生じる期待誤差を防ぐ ため閉眼状態で行った，刺激は，刺激速度により精神物 理学的絶対䦨值が変化する ${ }^{16)}$ ため, 可及的にゆっくり とした。本研究に扔いて歯根膜触・圧覚閾値の測定に 用いた精神物理学的測定法の極限法の一つである上下法 は，測定法に含まれる測定手続き自身に依存して生じる 恒常誤差を有する，恒常誤差には，被験者が系列中の変 化が今度こそは起こるだろうとかもう起こったはずだと する期待誤差と, 被験者が「慣れ」により同一の判断を 不当に繰り返し，普通より遅く変化に気がつくという傾 向から生じる慣れの誤差が含まれる。しかし，二つの方 向性を有した試行を重ねることにより，慣れの誤差と期 待誤差を減少させることができる ${ }^{17)}$. 本研究では与えら れた刺激に対し，「感じた」，「感じない」，つまり「○」 $「 \times 」 の$ 選択枝を用いた。閾值は直接測定することがで きず変曲点の中央值を求めることにより得られるため, 本研究では, 上昇系列, 下降系列の変曲点の中央值を歯 根膜触・圧覚閾值とした。

しかしながら歯根膜触・圧覚閾值の測定に, 被験者の 主観に委ねる部分が大きいことは否定できない。そこで 本研究では刺激部位, 速度, および術者を規定すること により，データの客観性を高めた。また被験者が眠気を 感じた際には実験を中断し, 眠気が改善されなかった場 合は実験を中止することで，被験者の自覚による誤差を 減少させた。

\section{2. 歯根膜触・圧覚閾值について}

Manly らはvon Freyの毛を用いて歯根膜触・圧覚間 值を測定し，歯軸方向では前歯部約 $1 \mathrm{~g}$, 大兒歯は 8 $10 \mathrm{~g}$ ，頬・唇方向ではこの $2 \sim 5$ 倍の感度であった ${ }^{9)}$ と 報告した。しかし, 本研究の健常被験者に打ける歯根膜 触・圧覚閾值の四分位範囲は, Manly らの報告と比較 し，各歯ともに大きい值を示した。山内 ${ }^{18)}$ らもわれわ れと同様に, Manly や Loewenstein らの報告した值よ りも大きい值を示している，その違いは，刺激の部位や 方向による歯根膜応答特異性 ${ }^{19)}$ にあると考える.

前歯部から後方に行くに従い大きな值を示す傾向は Manly ら $^{9)}$ と同様であった。前歯部は臼歯部と比較して 根尖部分の機械受容器の密度が高い ${ }^{20)}$ ため, 後方に行 くに従い大きい歯根膜触・圧覚閾值を示したと考えられ る。また左右同名歯は歯根膜感覚受容器数がほぼ同量と 推察されることから, 左右差は出現しなかったと考えら れる。

\section{3. 臨床例について}

窪木の「咬合違和感」に関する診断樹によると，咬 合違和感を訴える患者が来院した際には，まず訴える症 状に一致する明らかな咬合の不調和が認められるか検討 する，とされている ${ }^{1)}$ 。そこで，本研究ではまず咬合違 和感を認めず，正常咬合の基準を満たす健常被験者の歯 根膜触・圧覚閾值を測定した。異常を発見する過程にお いて，基準となる範囲を設定することは必要である。し かし，本研究で得られたデータはノンパラメトリックな データであり，通法に従う異常值の除去掞よび範囲設定 を行うことができない，そのため，臨床的参考值とし， 外机值や，異常值の影響を受けにくい四分位範囲を健常 被験者から求めた。この範囲の臨床的意義を, 咬合違和 感を自覚する臨床例で確かめた。

add 画像法による咬合検査の結果， $10 \% \mathrm{MVC}$ 時抒よ び $30 \% \mathrm{MVC}$ 時において $10 \mu \mathrm{m}$ 以下の領域の咬合接触 を両側臼歯部に認めた。また $10 \% \mathrm{MVC}$ 時と $30 \% \mathrm{MVC}$ 時の接触位置の変化を認めなかった。咬合接触像に異常 を認めなかったので，咬合違和感の原因としての知覚的 要素を示す歯根膜触・圧覚閾值を測定した。

なぜ，矯正治療終了 3 力月後まで歯根膜触・圧覚間值 の左右差がみられ，しかも大きな值を示したのかについ て，左右差が生じた理由として，臨床例の右側臼歯部に 交叉咬合を認め，交叉ゴムにより，より強い矯正力を右 側臼歯部に与えたためと考えられる。

そして，装置を除去したにも関わらず咬合違和感が直 ちに消失しなかった理由として，中枢性感作による二次 性痛覚過敏のためと考える.

IASP の分類委員会の知覚異常の定義によると, 炎症 による組織損傷の部位で起こる一次性痛覚過敏と, 損 傷の周りで起こる二次性痛覚過敏に分類される。そし て, 一次性痛覚過敏では侵害受容器の感作, 二次性痛覚 過敏では中枢性感作が原因であるといわれる ${ }^{21)}$.

矯正治療を開始すると矯正力負荷により痛覚間值が 低下し，歯の移動時には歯周組織に炎症性の変化が生じ る ${ }^{22)}$. 池田らによると，歯に強い咬合接触を加えると痛 覚閾值が低下し，違和感を生じる ${ }^{23)}$ 。また野寺らは歯根 膜機械受容器の応答闇值の上昇と痛覚閾值の低下が関連 していると報告した ${ }^{24)}$.

つまり歯に矯正力が加わることで一次性痛覚過敏が 生じ痛覚閾值が低下し，違和感が生じる。そして矯正 治療中に持続的な負荷が歯に加えられ，末梢からの侵害 性入力の持続によって二次性痛覚過敏が生じると考えら れる ${ }^{25)}$ 。さらに矯正装置除去後，二次性痛覚過敏状態の 持続とともに痛覚閾值は低下した状態を維持し，歯根膜 
触・圧覚閾値は上昇した状態を維持し, 違和感も持続し たと考えられる。

本床例に扔ける咬合違和感の発症は，2 年 7 カ月に わたり持続的に矯正力が歯に負荷され，中枢性感作によ る二次性痛覚過敏が原因であろう。したがって, 歯根膜 触・圧覚閾值がほぼ四分位範囲内に収束するまでに装置 除去 3.5 力月を要したものと考える.

その後, 装置除去後 7 カ月まで, 咬頭嵌合位での両側 臼歯同時均等接触が保たれ, 痛覚過敏状態の寛解が維持 されたものと考えられる。

\section{V. 結 論}

1. 健常有歯䫈者に歯根膜触・圧覚閾值の四分位範囲 は, 前歯から大臼歯にかけて後方にいくに従い大き な值を示した。

2. 矯正治療後において咬合違和感を自覚した患者にお いて, 歯根膜触・圧覚閾值が四分位範囲内へ収束す るとともに，歯の感覚の異常も消失した.

\section{文献}

1 ）窪木拓男. 補経歯科学から見た咬合違和感一咬合感 覚異常の疾患概念確立に向けて一，歯界展望 2011 ; 117 (1) : 136-137.

2) Clark G, Simmons M. Occlusal dysesthesia and tempromandibular disorders: is there a link? Alpha Omegan 2003; 96 (2): 33-39.

3 ) 玉置勝司, 和気裕之, 涉谷智明ほか。「咬合違和感」っ てナンだ?-GPが知っておきたい, その症状と実 態一. the Quintessence $2010 ； 29$ (12)：101-106.

4 ) 和気裕之。歯科心身医療の現状抢よび「歯科心身 症」に対する適切な医療と連携。心身医 $2009 ; 49$ (10) : 1003-1009.

5 ) 土佐淳一, 田中昌博, 川添堯涁ほか. 咬合接触のビ ジュアル化. 補綴誌 $1987 ； 31 ： 1553-1557$.

6 ) 土佐淳一, 田中昌博, 川添堯涁ほか. 䫈機能異常患 者の咬合接触状態の観察－add 画像による咬頭嵌 合位の接触状態. 下顎運動と EMG 論文集 $1989 ; 7$ ： 119-124.

7 ) 土佐淳一, 田中昌博, 川添堯涁ほか. add 画像にお ける咬合接触像の再現性に関する基礎的研究. 補緅 誌 $1993 ; 37$ : 1259-1264.

8 ) 田中昌博. 咬頭嵌合位での正常咬合の基準. 歯科医 学 $1999 ; 62: 249-252$.
9 ) Manly RS, Carl P, Donald DL et al. Oral sensory thresholds of persons with natural and artifical dentition. J Dent Res 1952; 305-312.

10) Loewenstein WR, Rathkamp R. A study on the pressoreceptive sensibility of the tooth. J Dent Res 1955; 34: 287-294.

11）玉井久貴. 歯牙および義歯床下粘膜の圧感覚刺激 に基づく咬合記録に関する研究. 歯科学報 1978; $78: 1751-1781$.

12) Oki K, Arima T, Takahashi S. et al. A new method for evaluating the threshold of periodontal ligament mechanoreceptor by slow speed mechanical stimulation. J Periodent Res 2003; 38: 482-487.

13) Garrett NR, Hasse AL, Kapur KK. Comparisons of tactile thresholds between implant-supported fixed partial dentures and removable partial denture. Int J Prosthodont 1992; 5: 515-22.

14）鈴木 祐, 小川 徹, 佐々木啓一ほか. 自家移植歯 の歯根膜触・圧覚閾值と咬合力負担に関する研究. 顎機能誌 $2008 ; 14: 104-105$.

15）村田洋一. 臼歯単独補綴歯冠の高さの調整が歯列咬 合接触に及ぼす影響 1 。シリコーン・ブラック法 に㧍ける咬みしめ強度。補綴誌 $1988 ； 32 ： 601-609$.

16) van Steenberghe D, Vries JH. Psychophysical threshold level of periodontal mechanoreceptors in man. Arch Oral Biol 1978; 23: 1041-1049.

17）中島義明. 実験心理学の基礎. 東京: 誠信書房; 2001, 105-114.

18）山内六男, 天野仁一朗, 川野襄二. インプラント 義歯装着者の口腔感覚に関する研究 第一報 骨内 インプラントの圧覚閾值について．補綴誌 1988 ; $32: 218-225$.

19) Trulsson M. Sensory-motor function of human periodontal mechanorecepter. J Oral Rehabil 2006; 33: 262-273.

20) Maeda T. Sensory innervation of the periodontal ligament in the incisor and molar of the monkey, Macaca fuscata : An immunohistochemical study for neurofilament protein and glia-specific S-100 protein. Arch Histol Jap 1987; 50: 437-457.

21) Stephen M, Martin K. Textbook of Pain, 5th ed. Philadelphia: Churchill Livingstone; 2005, 3-34.

22）山崎健一. 矯正学的歯の移動に伴う疼痛発現のメカ ニズムとその対応策. 矯正臨床ジャーナル 2007 ; $23: 35-45$. 
23）池田隆志. 強い咬合接触が歯の感覚および歯周組織 に及ぼす影響。補綴誌 $1987 ； 31 ： 675-688$.

24）野寺義典, 岡崎恵一郎, 鎌田勉. 矯正力負荷前後 にみられる歯根膜機械受容器と三叉神経主知覚核
ニューロンの応答. Orthodontic Waves 1998； 57 ： 10-24.

25) Stephen M, Martin K. Textbook of Pain, 5th ed. Philadelphia: Churchill Livingstone; 2005, 91-105. 